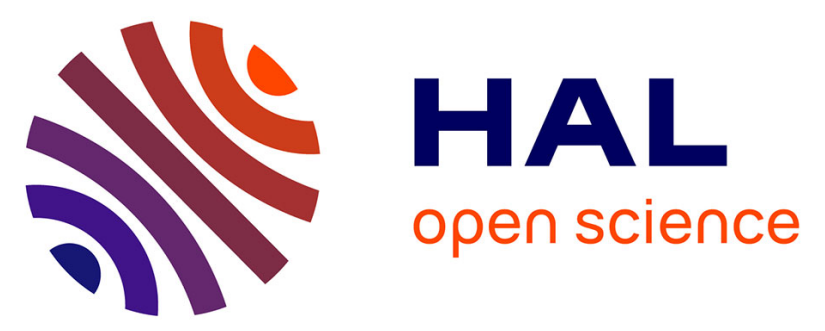

\title{
Correlation between degradation pathway and toxicity of acetaminophen and its by-products by using the electro-Fenton process in aqueous media
}

Thi Xuan Huong Le, Thi Van Nguyen, Zoulkifli Amadou Yacouba, Laetitia Zoungrana, Florent Avril, Duy Linh Nguyen, Eddy Petit, Julie Mendret, Valerie Bonniol, Mikhael Bechelany, et al.

\section{To cite this version:}

Thi Xuan Huong Le, Thi Van Nguyen, Zoulkifli Amadou Yacouba, Laetitia Zoungrana, Florent Avril, et al.. Correlation between degradation pathway and toxicity of acetaminophen and its byproducts by using the electro-Fenton process in aqueous media. Chemosphere, 2017, 172, pp.1-9. 10.1016/j.chemosphere.2016.12.060 . hal-01670990

\section{HAL Id: hal-01670990 \\ https://hal.umontpellier.fr/hal-01670990}

Submitted on 10 Jun 2021

HAL is a multi-disciplinary open access archive for the deposit and dissemination of scientific research documents, whether they are published or not. The documents may come from teaching and research institutions in France or abroad, or from public or private research centers.
L'archive ouverte pluridisciplinaire HAL, est destinée au dépôt et à la diffusion de documents scientifiques de niveau recherche, publiés ou non, émanant des établissements d'enseignement et de recherche français ou étrangers, des laboratoires publics ou privés. 
Degradation pathway and toxicity of acetaminophen by electro-Fenton processes in aqueous media

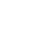

Thi Xuan Huong Le ${ }^{\mathrm{a}, \mathrm{b}}$, Thi Van Nguyen ${ }^{\mathrm{a}}$, Amadou Yacouba Zoulkiflia ${ }^{\mathrm{a}}$ Laetitia Zoungrana ${ }^{\mathrm{a}}$, Florent Avril ${ }^{\mathrm{a}}$, Duy Linh Nguyen ${ }^{\mathrm{a}}$, Eddy Petit ${ }^{\mathrm{a}}$, Julie Mendret ${ }^{\mathrm{a}}$, Valerie Bonniol ${ }^{\mathrm{a}}$, Mikhael Bechelany $^{\mathrm{a}}$, Stella Lacour ${ }^{\mathrm{a}}$, Geoffroy Lesage ${ }^{\mathrm{a}^{*}}$, Marc Cretin $^{\mathrm{a}^{*}}$

aIEM (Institut Europeen des Membranes), UMR 5635 (CNRS-ENSCM-UM), Université de Montpellier, Place E. Bataillon, F- 34095, Montpellier, France.

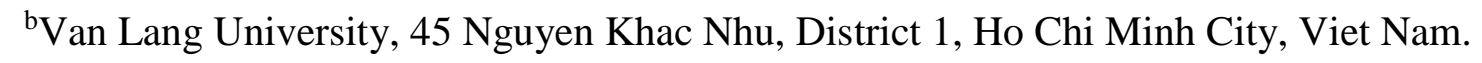

Corresponding author Email: Geoffroy.Lesage@umontpellier.fr, Marc.Cretin@umontpellier.fr

\begin{abstract}
The evolution of the degradation by-products of an acetaminophen (ACE) solution was monitored by HPLC-UV/MS and IC in parallel with its ecotoxicity (Vibrio fischeri 81.9\%, Microtox ${ }^{\circledR}$ screening tests) during electro-Fenton (EF) oxidation performed on carbon felt. The aromatic compounds 2-hydroxy-4-(N-acetyl) aminophenol, 1,4-benzoquinone, benzaldehyde and benzoic acid were identified as toxic sub-products during the first stage of the electrochemical treatment, whereas aliphatic short-chain carboxylic acids (oxalic, maleic, oxamic, formic, acetic and fumaric acids) and inorganic ions (ammonium and nitrate) were well identified as non-toxic terminal sub-products. Electrogenerated hydroxyl radicals then converted the eco-toxic and biorefractory property of initial ACE molecule $(500 \mathrm{~mL}, 1 \mathrm{mM})$ and subsequent aromatic subproducts into non-toxic compounds after $2 \mathrm{~h}$ of EF treatment. The toxicity of every intermediate produced during the mineralization of ACE was quantified, and a relationship was established
\end{abstract}


between the degradation pathway of ACE and the global toxicity evolution of the solution. After 8 $\mathrm{h}$ of treatment, a total organic carbon removal of $86.9 \%$ could be reached for $0.1 \mathrm{mM}$ ACE at applied current of $500 \mathrm{~mA}$ with $0.2 \mathrm{mM}$ of $\mathrm{Fe}^{2+}$ used as catalyst.

Key words: Carbon felt, Advanced Oxidation Process, TOC, Mineralization, By-products, Toxicity

\section{Introduction}

Over the past few years, pharmaceutical drugs have become a severe problem for the domestic wastewater treatment (Schwarzenbach et al., 2006). Pharmaceuticals such as anti-inflammatories, analgesics, lipid regulators, antibiotics, anti-epileptics, betablockers and oestrogens are used extensively for both humans and livestock. When consumed, 10-90\% of these drugs are metabolized. A significant quantity of the active ingredients is therefore excreted, mainly through urine and faeces, and collected in urban sewer systems or discharged directly into the environment by livestock. Many studies have confirmed the presence of a large number of medicinal substances in all environmental compartments: ground and surface water (Andreozzi et al., 2003; Leónidas A. Pérez-Estrada et al., 2005), drinking water (Ternes et al., 2002), tap water (Doll and Frimmel, 2003), ocean water, sediment and soil (Halling-Sørensen et al., 1998); this indicates the inefficiency of conventional water treatment processes to remove these kinds of micro-pollutants. Even if the amount of these pharmaceuticals in aquatic media is low, usually with concentrations lower than $10 \mu \mathrm{g} \mathrm{L}^{-1}$ (Ternes, 1998; Huerta-Fontela et al., 2011; Huerta et al., 2016), its continuous input constitutes at long term a real risk for aquatic and terrestrial organisms (Zhou et al., 2013; García-Mateos et al., 2015). Some pharmaceuticals are indeed suspected to affect the endocrine system of fishes, and available data on antibiotics indicate that they can exert toxic effects on algae and invertebrates and may favour the development of multi-drug resistant microbial strains (Zuccato et al., 2000; Balcığlu and Ötker, 2003). Among pharmaceuticals, 
acetaminophen (ACE) is an analgesic molecule consumed worldwide, and is usually selected by researchers as an emerging contaminant model (García-Mateos et al., 2015). ACE is also called paracetamol, and its chemical name is N-acetyl-p-aminophenol. This drug has been detected in European wastewater treatment plant (WWTP) with a concentration of $6 \mu \mathrm{g} \mathrm{L}^{-1}$ (Ternes, 1998), up to $10 \mu \mathrm{g} \mathrm{L}^{-1}$ in natural water resource in the USA (Kolpin et al., 2002) and more than $65 \mu \mathrm{g} \mathrm{L}^{-1}$ in the Tyne River, UK (Kabdaşli et al., 1999; Roberts and Thomas, 2006).

Because of the toxicity and persistency of pharmaceuticals, it is necessary to develop powerful methods to ensure complete degradation of pharmaceutical pollutants as well as their potentially toxic degradation by-products. Conventional technologies that are currently used, such as activated carbon adsorption, flocculation, biological degradation, and chemical process like chlorination, have the disadvantages of being poorly efficient for non-biodegradable compounds or to transfer the pollutants into the solid phase (sludge or sorbent). Pollution is, in this case, only displaced and not solved. Advanced oxidation processes (AOPs) (Ozonation, $\mathrm{UV} / \mathrm{H}_{2} \mathrm{O}_{2}$, electroand photo-Fenton) can be easily incorporated in pre-existing treatment plants and were found to achieve efficient reduction of micropollutant discharge in the aquatic environment (Reungoat et al., 2010; Reungoat et al., 2012; Eggen et al., 2014; Sirés et al., 2014; Moreira et al., 2017). Because non-selective radicals such as hydroxyl radicals $(\mathrm{OH})$ are generated, AOPs are considered a competitive water treatment technology for the degradation of these refractory organic micropollutants and the improvement of effluent quality from treatment plants (Gerrity et al., 2011; Giannakis et al., 2015). Several publications have highlighted the potentialities of AOPs such as $\mathrm{UV} / \mathrm{H}_{2} \mathrm{O}_{2}$ (Frontistis et al., 2012; Lee et al., 2016); ozonation (Huber et al., 2005; Gerrity et al., 2011; Zimmermann et al., 2011; Reungoat et al., 2012; Margot et al., 2013), Fenton and photo-Fenton (Tekin et al., 2006; Kulik et al., 2008), semiconductor photocatalysis (Molinari et al., 2006; Abellán et al., 2007), and electrochemical separation and degradation technologies (Sirés and Brillas, 2012) to eliminate biorefractory pharmaceuticals. Recently, textural 
modification of carbon felt (Le et al., 2016) and graphene deposition on graphite substrates (Le et al., 2015a\&b) have shown a great potential to enhance mineralization of the azo dye acid Orange 7 and $\mathrm{ACE}$ by the electro-Fenton $(\mathrm{EF})$ process. Derived Fenton processes have also already proved to be efficient methods to degrade ACE from water: combined EF and photo-Fenton using a double cathode electrochemical cell (de Luna et al., 2012), coupling adsorption and photo-Fenton using nano-zeolites and cobalt ferrite nanoparticles (Irani et al., 2015), bio-electrochemical degradation in a microbial fuel cell-Fenton system (Zhang et al., 2015), or other methods relevant to the photo-Fenton process (Trovó et al., 2008; Trovo et al., 2012; Cabrera Reina et al., 2015; Rad et al., 2015). As a more detailed example, Sirés et al. could totally mineralize ACE in $\mathrm{CO}_{2}$ after $6 \mathrm{~h}$ of treatment by using the catalytic action of $\mathrm{Fe}^{2+}, \mathrm{Cu}^{2+}$ and UVA light to generate hydroxyl radicals. During the electrolysis, several by-products were detected, such as hydroquinone, p-benzoquinone, or short chain carboxylic acids (Sirés et al., 2006). Using the solar photoelectro-Fenton (SPEF) method, ACE was efficiently mineralized in the study of Lucio Cesar Almeida et al. (Almeida et al., 2011). In particular, after 120 min of electrolysis, total organic carbon (TOC) removal attained was $75 \%$ with an energy cost of $93 \mathrm{kWhkg}^{-1}$ TOC $\left(7.0 \mathrm{kWhm}^{-3}\right)$ and a mineralization current efficiency of $71 \%$. In addition, many by-products including aromatic compounds as well as carboxylic acids were adequately detected, such as hydroquinone, pbenzoquinone, 1,2,4-trihydroxybenzene, 2,5-dihydroxy-p-benzoquinone and tetrahydroxy-pbenzoquinone, maleic, fumaric, succinic, lactic, oxalic, formic and oxamic acids. In addition, the combination of adsorption and photo-Fenton method by Irani et al. could lead to $99.80 \%$ of paracetamol removal in 30 min (Irani et al., 2015).

Depending on the AOP technique used, several degradation pathways of ACE have been identified and already published (Andreozzi et al., 2003; Brillas et al., 2005; Skoumal et al., 2006; Yang et al., 2008a). All authors observed the formation of reactive by-products due to partial oxidation of the initial molecule and reaction with matrix components (Von Gunten, 2003). It is important to track the intermediates generated through degradation reactions and to know their 
eco-toxicity, with the view to verify the safety of the water treatment process. Unfortunately, very few works were aimed at combining analytical chemistry to individual and global toxicity measurement of both products and solution during AOP treatment (Hamdi El Najjar et al., 2014) as presented in this study.

Research at laboratory and pilot scale clearly demonstrated that AOPs can be applied to improve the quality of effluents from municipal and industrial WWTPs by attenuating trace organic contaminants (micropollutants) (Gerrity et al., 2011; Giannakis et al., 2015). However, a potential disadvantage of these processes is the formation of unknown reactive by-products due to partial oxidation of the targeted compounds and reaction with matrix components (von Gunten, 2003). Thus, the final toxicity of treated effluent should be determined together with the quantity of targeted compounds in terms of the detection limits of the analytical protocols. In this study, the EF reaction was applied to ACE solution. ACE and its by-products generated during the degradation were monitored by HPLC-UV/MS, IC and TOC analysis. In addition, acute toxicity of the ACE solution under EF treatment as well as individual and mixed intermediate standards were assessed through Microtox ${ }^{\circledR}$ toxicity test with Vibrio Fischeri marine bacteria. Through this study, the relationship between the ACE degradation pathway, the individual by-product toxicity and the global toxicity of the solution could be newly and clearly established, thus providing a more comprehensive understanding and safety control of the mineralization process of ACE by the EF process.

\section{Experimental}

\subsection{Materials}

ACE (acetaminophen: paracetamol), sodium sulphate (anhydrous, 99.0-100.5\%), sodium hydroxide (99\%), sulphuric acid (95-97\%), iron (II) sulphate hepta-hydrate (99\%), benzoquinone, benzaldehyde, benzoic acid, oxalic acid, maleic acid, oxamic acid, formic acid, fumaric acid and acetic acid were obtained from Sigma-Aldrich, USA. Bacterial strain of Vibrio fischeri NRRL B- 
11177 involved in toxicity tests was obtained from Hach Lange GmbH, Germany. Osmotic adjusting solution (MilliQ water with $22 \% \mathrm{NaCl}$ ) and diluent (MilliQ water with $2 \% \mathrm{NaCl}$ ) were used for the preparation of the bacterial solution. The carbon felt was purchased from A Johnson Matthey Co., Germany. TOC standard of $1000 \mathrm{mg} \mathrm{L}$ L $^{-1}$ (Sigma-Aldrich, USA) and sodium hydrogen carbonate ( $\geq .99 .5 \%$, ACS, Karlsruhe, Germany) were used for TOC and inorganic carbon (IC) calibration curves assessments, respectively.

\subsection{Electrochemical system for ACE degradation}

EF experiments were performed at room temperature in a 500-mL single cylindrical glass cell with a two-electrode system. The applied current was controlled using a power supply (Lambda Electronic, USA) in a galvanostatic mode. The carbon felt cathode $\left(60 \mathrm{~cm}^{2}\right)$ was used as a working electrode and a platinum cylindrical mesh as a counter electrode. The anode was centred in the electrolytic cell, surrounded by the cathode, which covered the inner wall of the cell. The distance between the electrodes was $1.5 \mathrm{~cm}$. The aqueous solution of ACE, $\mathrm{Na}_{2} \mathrm{SO}_{4}(50 \mathrm{mM})$ as the supporting electrolyte and $\mathrm{FeSO}_{4} \cdot 7 \mathrm{H}_{2} \mathrm{O}$ as the catalyst were prepared by adjusting the $\mathrm{pH}$ at 3.0 with sulphuric acid $\left(\mathrm{H}_{2} \mathrm{SO}_{4}\right)$. The intermediate compound monitoring experiment was performed in $500 \mathrm{~mL}$ solution of ACE $1 \mathrm{mM}$ and/or $200 \mathrm{~mL}$ solution of ACE $0.1 \mathrm{mM}$ with $\mathrm{FeSO}_{4} .7 \mathrm{H}_{2} \mathrm{O}(0.2 \mathrm{mM})$ at an applied current of $500 \mathrm{~mA}$. Before the electrolysis, oxygen bubbling was performed for $5 \mathrm{~min}$ to saturate the solutions, and the solutions were kept under continuous magnetic stirring at a rate of $800 \mathrm{rpm}$ during the experiment.

The specific energy consumption per unit TOC mass ( $\left.\mathrm{EC}_{\mathrm{TOC}}\right)$ was calculated by Eq. (1) (Ruiz et al., 2011):

$$
\mathrm{EC}_{\mathrm{TOC}}\left(\mathrm{kWh} \mathrm{g}^{-1} \mathrm{TOC}\right)=\frac{\mathrm{VIt}}{(\Delta \mathrm{TOC})_{\exp \mathrm{s}_{\mathrm{s}}}}(1)
$$

where $\mathrm{V}$ is the average cell voltage $(\mathrm{V}), \mathrm{V}_{\mathrm{s}}$ is the solution volume $(\mathrm{L}), \Delta(\mathrm{TOC})_{\exp }$ is the experimental TOC decay $\left(\mathrm{mg} \mathrm{L}^{-1}\right)$, I is the applied current (A) and $\mathrm{t}$ is the electrolysis time (h). 


\subsection{Analytical procedures}

Concentrations of ACE and their aromatic oxidation by-products were analysed by a HPLC system (Waters 717 Autosampler and Waters 616 Pump) with a Photodiode Array Detector (Waters 2996 Photodiode Array Detector) fitted with a reverse phase Thermo Scientific C18 column ( $\mathrm{L}=250 \mathrm{~mm}$, I.D=4.6 $\mathrm{mm}$, and $5-\mu \mathrm{m}$ particle size). The column temperature was thermostated at $30^{\circ} \mathrm{C}$. The injection volumes were $20 \mu \mathrm{L}$. The mobile phase was constituted of buffer A (HPLC grade water $+0.1 \%(\mathrm{v} / \mathrm{v})$ trifluoroacetic acid) and buffer B (HPLC grade acetonitrile $+0.1 \%(\mathrm{v} / \mathrm{v})$ trifluoroacetic acid). The flow rate was $1 \mathrm{~mL} \cdot \mathrm{min}^{-1}$. The eluent gradient started with $10 \%$ of eluent B, gradually increasing to $70 \%$ in 35 min. Eluent B was elevated to $90 \%$ in $5 \mathrm{~min}$, and the system was kept for $5 \mathrm{~min}$, returning to $10 \%$ in $1 \mathrm{~min}$ and equilibrating for 9 min (returning to initial condition and re-equilibrating the column). UV detection was performed at $\lambda=254 \mathrm{~nm}$ for substituted benzene structure monitoring.

The degradation products of ACE were identified by an LC-MS system. LC-MS was performed with an Alliance e2695 (Waters HPLC pump and autosampler system), and a QuattroMicro mass spectrometer was equipped with an Electrospray probe (Waters Micromass, Wythenshawe, Manchester, UK). The detection conditions were as follows: capillary potential of $3.5 \mathrm{kV}$, cone voltage of $30 \mathrm{~V}$, source temperature of $120^{\circ} \mathrm{C}$, desolvation temperature of $450^{\circ} \mathrm{C}$, cone gas flow of $50 \mathrm{~L} \mathrm{~h}^{-1}$ and desolvation gas flow of $450 \mathrm{~L} \cdot \mathrm{h}^{-1}$. Nitrogen was used as the nebulizer gas. A Waters column HSST3 (L=100 mm, D.I= $2.1 \mathrm{~mm}$, and 5- $\mu \mathrm{m}$ particle size) was used to separate intermediates. The column was set at room temperature $\left(22^{\circ} \mathrm{C}\right)$. The injection volumes were $20 \mu \mathrm{L}$. The mobile phase comprised buffer A (HPLC grade water $+0.1 \%(\mathrm{v} / \mathrm{v}$ ) formic acid) and buffer B (HPLC grade acetonitrile $+0.1 \%(\mathrm{v} / \mathrm{v})$ formic acid). The flow rate was $0.25 \mathrm{~mL} \mathrm{~min}^{-1}$. The eluent gradient started with $10 \%$ of eluent B and was kept for $1 \mathrm{~min}$, gradually increasing to $90 \%$ in $2 \mathrm{~min}$, and the system was then kept for $1 \mathrm{~min}$, returning to $10 \%$ in $1 \mathrm{~min}$ and equilibrating for $2 \mathrm{~min}$ (returning to initial condition and re-equilibrating the column). The eluent from the chromatographic column successively entered the UV-Vis diode array detector (Waters 
PDA996) and the electrospray ionization (ESI) interface of the mass spectrometer. Mass spectrometry (MS) analysis was performed in a positive mode. The mass range was $90-400$ (m/z). The eluted components having specific retention time were characterized by their UVspectra and/or their mass. The quantification using the standard addition method (HPLC-UV) or external calibration against standard (LC-MS) was performed. Short-chain acids were identified and quantified using the HPLC-UV system already described, but fitted with a SHODEX KC 811 (D.I=8 $\mathrm{mm}, \mathrm{L}=300 \mathrm{~mm}$ and $7-\mu \mathrm{m}$ particles) column, which was thermostated at $30^{\circ} \mathrm{C}$. UV detection was performed at $\lambda=210 \mathrm{~nm}$. The mobile phase was buffer A (HPLC grade water $+0.1 \%$ (v/v) Phosphoric acid $85 \%$ ). The flow rate was $0.50 \mathrm{~mL} \mathrm{~min}^{-1}$.

Inorganic ions $\left(\mathrm{NO}_{3}{ }^{-}, \mathrm{NH}_{4}{ }^{+}\right)$generated during decomposition of $\mathrm{ACE}$ were identified by an ion chromatography equipment. For anion, Dionex ICS-1000 system was connected to an AS19 column $(4 \mathrm{~mm} \times 250 \mathrm{~mm})$, and the eluent $\mathrm{KOH}$ was applied according to the elution gradient: 10 $\mathrm{mM}$ in $10 \mathrm{~min}$, then gradient in $20 \mathrm{~min}$ to $45 \mathrm{mM}$. Dionex ICS-900 was used to measure the cation concentration in the treated solution with the column CS12A and 20-mM methane sulphonic acid as eluent. Both columns were thermally controlled at $30^{\circ} \mathrm{C}$, and DS6 conductivity detector was used.

The TOC and the IC of the initial and treated samples were determined using a TOC-L CSH/CSN Shimadzu (Japan) analyser. Calibration curves for TOC and IC analysis were constructed by automatic dilution on the same machine from solutions of TOC standard of 1000 $\mathrm{mg} / \mathrm{L}$ and sodium hydrogen carbonate.

\subsection{Toxicity tests}

The Microtox ${ }^{\circledR}$ bacterial toxicity test is based on the general principles described by ISO (2007) (Romero et al., 2008). The toxicity of ACE and its intermediate by-products formed during 
its degradation was determined by measuring the effect on the luminescence of marine bacteria. Bacterial luminescence was measured using a Microtox ${ }^{\circledR}$ Model 500 Analyzer (Modern Water Inc., UK). The bacterial strain used in this method was Vibrio fischeri NRRL B-11177. During growth, this bacterium emitted luminescence that was related to its cellular respiration and cell activity. As the activity of the bacterial cell could be reduced by the presence of toxic elements, bioluminescence is therefore a very good indicator of state of the bacterium and thus of the global toxicity of the sample.

This device allowed for performing the acute toxicity tests by using the software MicrotoxOmni®. To identify the relative toxicity of each samples solution, an $81.9 \%$ screening test was used to characterize the inter-sample toxicity variability: the influence of treatment processes on the effluent toxicity was monitored with a sampling method performed as a function of time. The test performed in this study is called $81.9 \%$ screening test because all samples were diluted at $81.9 \%$ of the initial sample concentration by adding a $22 \% \mathrm{NaCl}$ solution to allow $\mathrm{V}$. fischeri normal activity and thus luminescence emission. Before measuring the bacterial luminescence, $\mathrm{pH}$ of the samples were adjusted between 6.5 and 7.5 by sodium hydroxide or sulphuric acid, and filtration was then performed with a $0.2-\mu \mathrm{m}$ syringe filter to eliminate any precipitate or solid matter in the solution.

In the absence of toxicity, the luminescence of bacteria decreases over time under the effect of environmental conditions. Thus, it is necessary to compensate the errors due to these factors by considering the variability of the luminescence $\mathrm{R}(\mathrm{t})$ of the bacteria in a control solution (MilliQ water and $\mathrm{NaCl}$ ), which gives the LU0 values. Equation (2) gives the corrected term $\mathrm{R}(\mathrm{t})$.

$$
R(t)=\frac{\mathrm{LU} 0(\mathrm{t})}{\mathrm{LU} 0(0)}
$$

where LUO(t) is the intensity of luminescence emitted by bacteria after a $t=5 \mathrm{~min}$ or $\mathrm{t}=15 \mathrm{~min}$ of contact with the control solution (MilliQ water and $\mathrm{NaCl}$ ) (Arbitrary Units (A.U.)); and LUO(0) is the initial intensity of luminescence emitted by bacteria before the addition of the control solution (MilliQ water and $\mathrm{NaCl}$ ) (A.U.). 
then calculated using Eq. (3). To simplify, $\mathrm{I}(\mathrm{t})$ is called "Inhibition" hereafter (Figs. 5, 6 and 7) and is expressed as percentage.:

$$
\mathrm{I}(\mathrm{t})(\%)=\left(1-\frac{\mathrm{LU}(\mathrm{t})}{R(t) \mathrm{LUU}(0)}\right) \times 100
$$

where $L U(t)$ is the intensity of luminescence emitted by bacteria after a $t=5$ min or $t=15$ min of contact with the sample (A.U.) and $L U(0)$ is the initial intensity of luminescence emitted by bacteria before the addition of the sample (A.U.).

Furthermore, eco-toxicity tests were performed on the commercially available by-products to confirm the toxicity of the compounds formed during the degradation of the main molecule, ACE. These by-products and their mixtures were prepared with the maximum concentrations detected by HPLC analysis during the EF experiment.

\section{Results and discussion}

\subsection{Degradation pathway of acetaminophen during the EF process}

\subsubsection{Evolution of aromatic compounds}

The degradation of ACE by the EF process formed some aromatic compounds such as 1,4benzoquinone, benzaldehyde and benzoic acid identified by HPLC (Fig. 1) and 2-hydroxy-4-(Nacetyl) aminophenol identified by $\mathrm{r}$ LC/MS (Table S1). It was noted that at the beginning of the ACE degradation, 1,4-benzoquinone was the main aromatic by-product identified. Its highest concentration reached $0.23 \mathrm{mM}$ after 10 min of the degradation process; its concentration then decreased, and this product disappeared totally after $120 \mathrm{~min}$. The other identified aromatic intermediates are also detected at a very short time of decomposition process with a concentration peak of 0.09 and $0.039 \mathrm{mM}$ at 14 and $10 \mathrm{~min}$ for benzoic acid and benzaldehyde, respectively. These aromatic compounds were totally decomposed after $120 \mathrm{~min}$ of electrolysis and were 

balance.

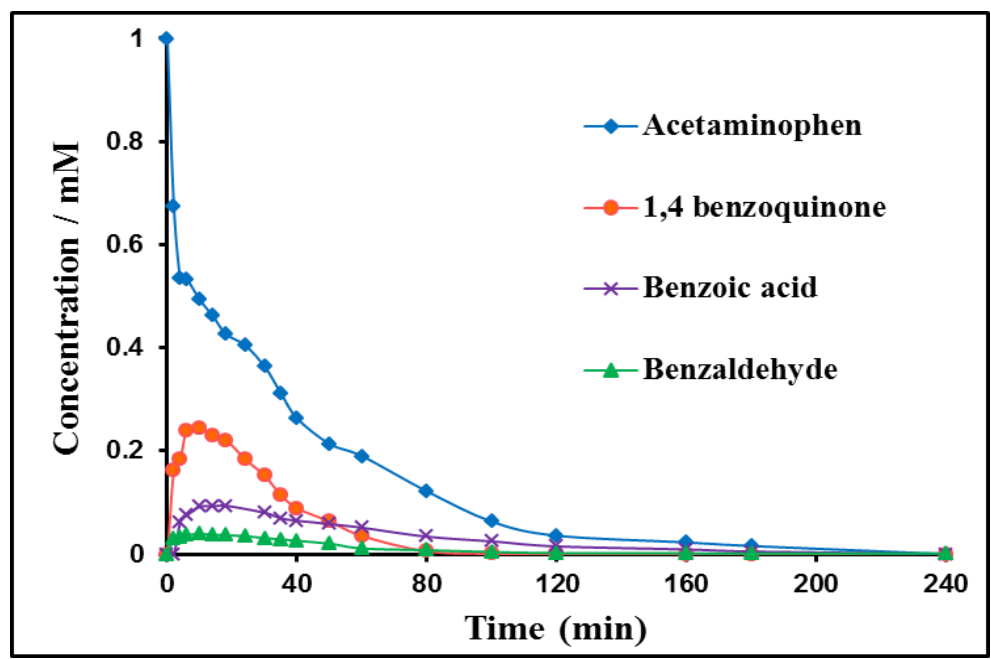

Fig. 1. Evolution of the concentration of ACE and the aromatic degradation by-products (RSD 2\% $\mathrm{n}=3$ ) during EF treatment of $500 \mathrm{~mL}$ ACE solution at $\mathrm{C}_{0}=1.0 \mathrm{mM} ; \mathrm{pH}=3 ;\left[\mathrm{Na}_{2} \mathrm{SO}_{4}\right]=50 \mathrm{mM}, \mathrm{I}=$ $500 \mathrm{~mA}$ and $\left[\mathrm{Fe}^{2+}\right]=0.2 \mathrm{mM}$.

\subsubsection{Evolution of short-chain carboxylic acids}

The evolution of carboxylic acid concentration during the electrolysis treatment of a 1.0mM ACE aqueous solution at $\mathrm{pH} 3.0$ is reported in Fig. 2. These by-products are usually found in ACE degradation by AOPs such as ozonation (Skoumal et al., 2006) or electrogenerated hydrogen peroxide process (Reungoat et al., 2010). Oxalic, maleic, oxamic, formic, acetic and fumaric acids were detected at 11.6, 13.59, 15.23, 20.59, 22.25 and $22.89 \mathrm{~min}$ of retention time, respectively, during the degradation experiment. Figure 2 shows that fumaric and oxamic acids were generated after around 20 min of electrolysis, while the other by-products such as maleic, acetic, formic and oxalic acids were detected only after $3 \mathrm{~h}$. The accumulation of oxalic acid is well known in Fenton-related processes because of the formation of iron-oxalate complexes that are slowly removed by ${ }^{\circ} \mathrm{OH}$. At the end of the EF treatment $(8 \mathrm{~h})$, fumaric, acetic and formic acids were completely removed from solution, while oxalic and maleic acid were still present in the solution. 
Singularly, oxamic acid concentration remained high (around $0.52 \mathrm{mM}$ ) after $8 \mathrm{~h}$ of treatment, with a TOC removal of 51\%. This indicated that oxamic acid remained stable under our experimental conditions.
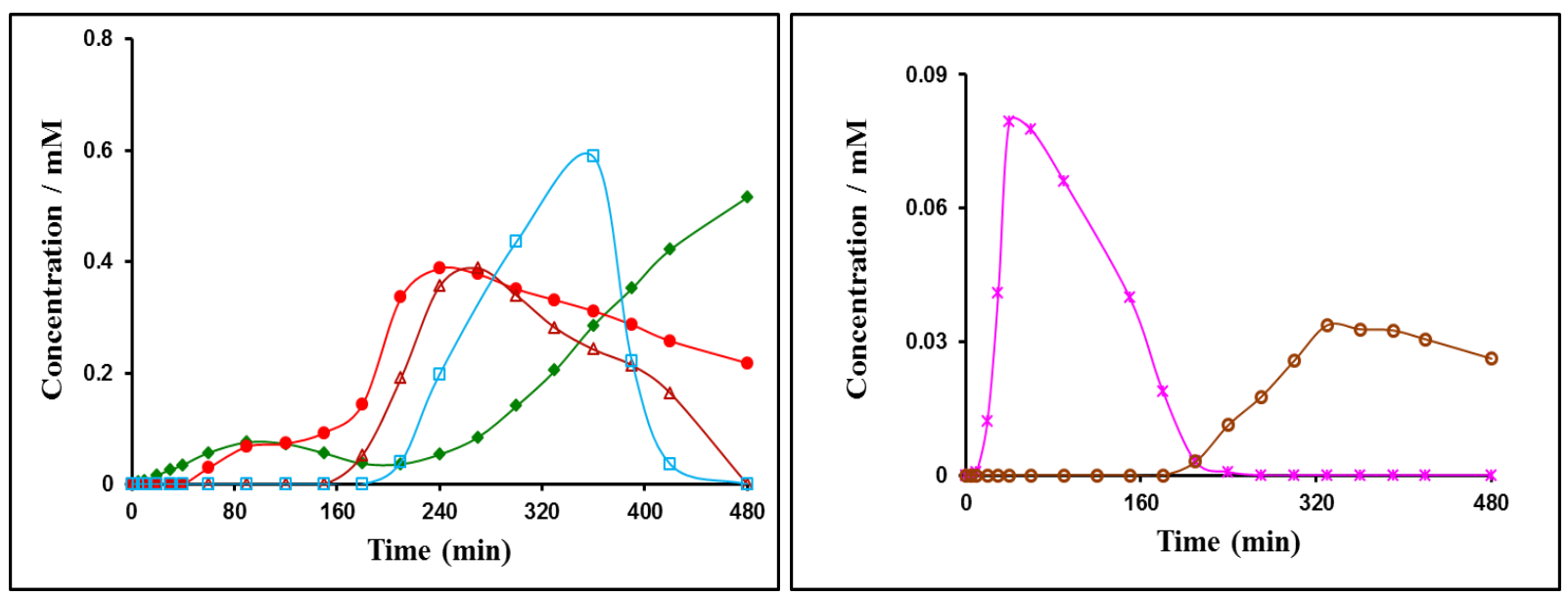

Fig. 2. Evolution of the concentration of carboxylic acids (RSD 2\% $n=3$ ) during EF degradation of

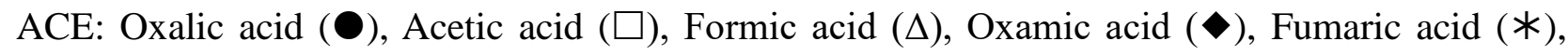
Maleic x $10(\bigcirc)$. Conditions: $500 \mathrm{~mL}$ ACE solution at $\mathrm{C}_{0}=1.0 \mathrm{mM} ; \mathrm{pH}=3 ;\left[\mathrm{Na}_{2} \mathrm{SO}_{4}\right]=50 \mathrm{mM}$, I $=500 \mathrm{~mA}$ and $\left[\mathrm{Fe}^{2+}\right]=0.2 \mathrm{mM}$.

\subsubsection{Evolution of inorganic ions}

The mineralization of ACE and their intermediates also produced inorganic ions. Ammonium and nitrate concentrations were monitored during the $8 \mathrm{~h}$ of treatment (Fig. 3). Nitrate was measured at very low concentrations compared to ammonium. As observed by E. Brillas et al. (Brillas et al., 2009), the first limiting step of ACE degradation is the hydroxylation reaction leading to 2-hydroxy-4-(N-acetyl) aminophenol (Table 1), which is then converted into oxamic acid. The presence of $\mathrm{Fe}^{2+}$ in the solution as catalyst could lead to the concomitant production of persistent iron-oxamate complexes, which are very difficult to mineralize by $\bullet \mathrm{OH}$, thus limiting the oxidation ability of the EF process. Therefore, nitrate was clearly detected and quantified only after $2 \mathrm{~h}$ of treatment and reached $0.02 \mathrm{mM}$ in $8 \mathrm{~h}$, while ammonium concentration reached up to $0.38 \mathrm{mM}$ at the same time (Fig. 3). At the end of the treatment process, the initial nitrogen- 
containing compound $(1 \mathrm{mM})$ was converted into oxamic acid $(0.52 \mathrm{mM})$, ammonium $(0.38 \mathrm{mM})$ and trace of nitrate $(0.02 \mathrm{mM})$ (Figs. 2 and 3). Therefore, a total of $0.92 \mathrm{mM}$ of $\mathrm{N}$ in by-products was quantified, which means that the nitrogen mass balance is confirmed, considering that around $8 \%$ of nitrogen lost during the EF process could be explained by the fact that nitrogen could be transferred to the volatile phase through $\mathrm{N}_{2}$ and $\mathrm{NH}_{3}$ apparition (Hammami et al., 2008).

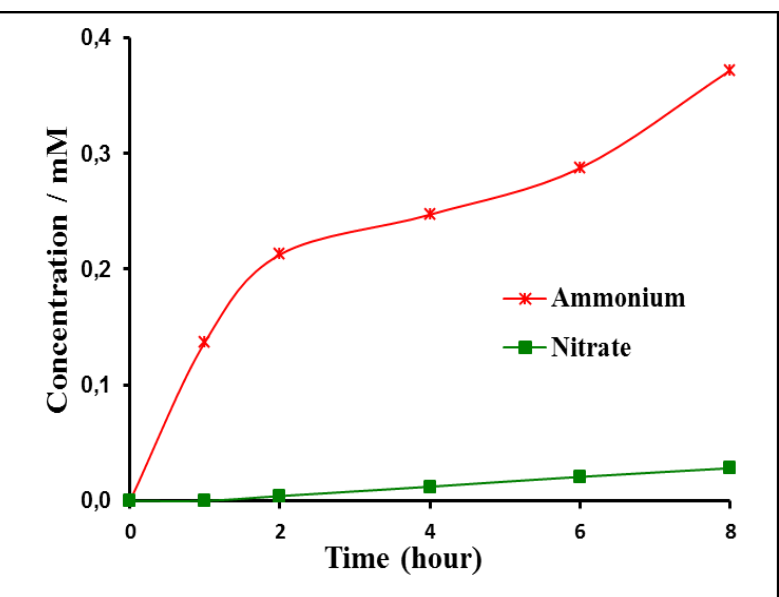

Fig. 3. Evolution of the inorganic ions concentration (RSD 5\% n=3) during EF degradation of ACE. Conditions: $500 \mathrm{~mL}$ ACE solution at $\mathrm{C}_{0}=1.0 \mathrm{mM}$; $\mathrm{pH}=3 ;\left[\mathrm{Na}_{2} \mathrm{SO}_{4}\right]=50 \mathrm{mM}, \mathrm{I}=500 \mathrm{~mA}$ and $\left[\mathrm{Fe}^{2+}\right]=0.2 \mathrm{mM}$.

\subsubsection{Degradation pathway of ACE mineralization during the EF process}

After $8 \mathrm{~h}$ of treatment, almost $90 \%$ of organic compounds in the initial ACE solution (200 $\mathrm{mL}$ at $0.1 \mathrm{mM}$ ) were mineralized, proving the efficiency of the EF process for removing the pharmaceutical pollutants (Fig. S1). The specific energy consumption in 120 min was calculated at $3.6 \mathrm{kWh} \mathrm{g}^{-1} \mathrm{TOC}$, which is a low value, proving the interest of the system, compared to the reported value of $93 \mathrm{kWh} \mathrm{g}^{-1}$ TOC obtained by the solar SPEF method (Almeida et al., 2011).

A general reaction sequence for the EF degradation of ACE in acidic medium is proposed in Fig. 4. The process was initiated by ${ }^{\bullet} \mathrm{OH}$ radical attack either on the $\mathrm{C}(2)$ position of ACE (I), which led to the formation of 2-hydroxy-4-(N-acetyl)aminophenol (II), or on its $\mathrm{C}(4)$-position 
which led to 1,4-benzoquinone (III). The formation of these intermediate products could also be 289 proposed in other AOP processes during the degradation of ACE (Yang et al., 2008b). 2-Hydroxy290 4-(N-acetyl) aminophenol (II) was then degraded into benzoic acid (V), benzaldehyde (IV) and 291 acetamide. Subsequently, all aromatic by-products were further oxidized to produce aliphatic 292 organic acids such as fumaric, oxalic, acetic, formic and maleic acids. Furthermore, oxamic acid 293 was generated from the oxidation of acetamide (Skoumal et al., 2006). At the end of the 294 degradation process, unlike oxamic and oxalic acids which persisted under our experimental 295 conditions, all these last by-products were transformed into $\mathrm{CO}_{2}, \mathrm{H}_{2} \mathrm{O}$ and inorganic ions. 


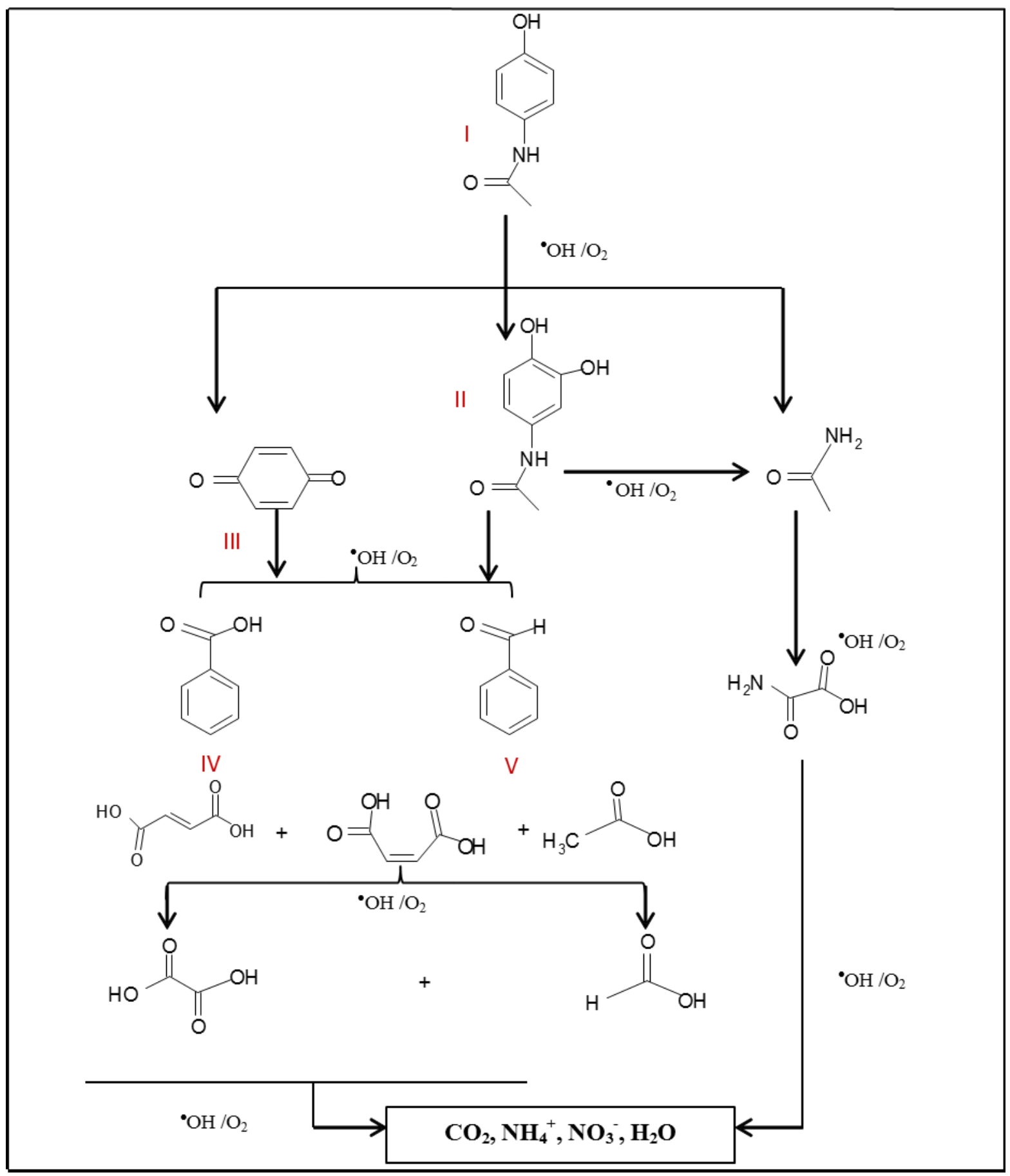

Fig. 4. General reaction sequence proposed for acetaminophen (ACE) mineralization in an acidic 299 medium by hydroxyl radicals during the EF process. 
treatment is shown in Fig. 5. The acute toxicity of the treated solution after 5- and 15-min time contact with $V$. fischeri bacterial strain increased rapidly at the early stage of the treatment and reached $100 \%$ between 2 and $55 \mathrm{~min}$. This result is relevant and consistent with regard to the previously proved formation of toxic aromatic by-products such as 1,4-benzoquinone, benzoic acid and benzaldehyde (Lee and Chen, 2009; Das et al., 2010; Dirany et al., 2012). After 60 min, the toxicity markedly declined which well agreed with aromatic compounds found only at trace levels at this stage of the EF reaction (see part 2.1.1 and Fig. 1). The predominance of very low toxic short-chain carboxylic acids in this period did not significantly contribute to the inhibition of the bacterial luminescence; consequently, the solution toxicity became zero at about $120 \mathrm{~min}$. Subsequently, the inhibition value was continuously maintained at around zero until $8 \mathrm{~h}$ where short-chain carboxylic acids were continuously transformed under $\bullet \mathrm{OH}$ attack during the EF process. The two exposure times measured yielded identical inhibition (\%) results.

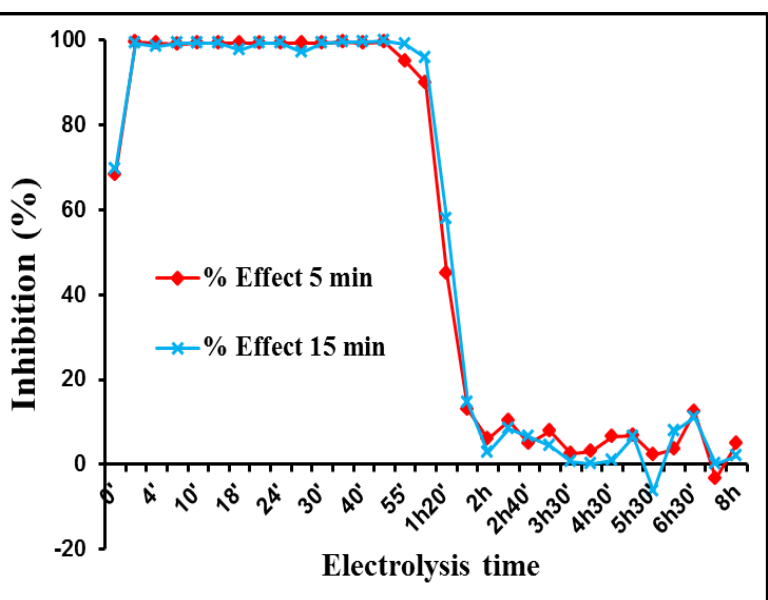

Fig. 5. Inhibition of luminescence of $V$. fischeri marine bacteria during EF treatment of $500 \mathrm{~mL}$ of $1 \mathrm{mM}$ ACE at $\mathrm{pH}=3.0 ;\left[\mathrm{Na}_{2} \mathrm{SO}_{4}\right]=50 \mathrm{mM}, \mathrm{I}=500 \mathrm{~mA},\left[\mathrm{Fe}^{2+}\right]=0.2 \mathrm{mM}$. Two exposure time of the bacterial strain to the treated solution were used ( 5 and $15 \min )$. RSD $(n=5): 12 \%$ for inhibition < $20 \%$; $5 \%$ for $20 \%<$ inhibition $<70 \%$ and $0 \%$ for inhibition $>70 \%$.

\subsubsection{Toxicity of intermediate sub-products}



investigated by the ecotoxicity assays. Their concentration was selected with regard to those analysed during the ACE degradation. For this purpose and according to by-products formation shown in Fig. 2, specific times of EF treatment were considered: 10, 60, 80 and 120 min corresponding to different mixture solutions and concentrations of by-products (Table S2).

As shown in Fig. 6a, b, c and d, ACE itself is not a hazardous pollutant for this strain of bacteria because its toxicity was very low even at the high concentration $(0.5 \mathrm{mM})$ found after 10 min of treatment. Similarly, benzoic acid was also a low toxic by-product because its negative toxicity values towards the bacterial strain during the degradation process signifies a positive effect on bacteria growth and activity (Velegraki et al., 2010). In contrast, 1,4benzoquinone showed an important toxic effect as the inhibition ratio was around $100 \%$ even at very low amount, $0.04 \mathrm{mM}$ (60-min degradation), compared to other formed aromatic intermediates. Although benzaldehyde was not as toxic as 1,4-benzoquinone, this compound still largely affected bacterial luminescence (Paulraj et al., 2011). It caused an acute toxicity between about $50 \%$ and $20 \%$ at the concentration of $0.039 \mathrm{mM}(10 \mathrm{~min})$ and $0.002 \mathrm{mM}(120$ min), respectively. In addition, the mixtures of these aromatic compounds at four periods from 10, 60, 80-120 min were ecotoxically assessed (Fig. 6e). The inhibition ratio reached $100 \%$ at the early stage of the treatment (10 and $60 \mathrm{~min})$, again proving the high toxicity of 1,4benzoquinone. This agrees with previously published results (Rubio et al., 2011). Subsequently, a remarkable detoxification was observed after 80 and $120 \mathrm{~min}$ due to the decline of the corresponding toxic aromatics. 

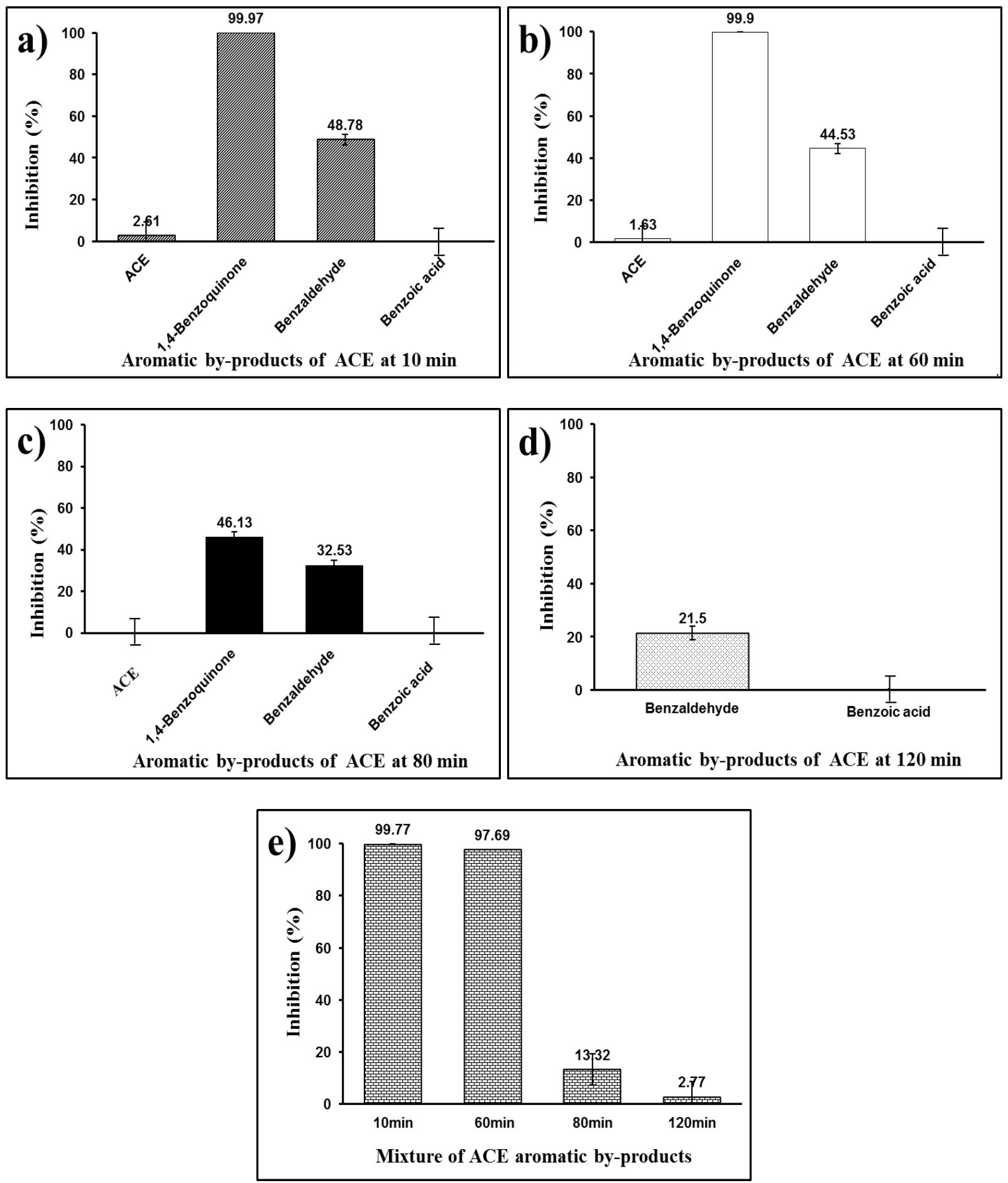

Fig. 6. Toxicity of standard solutions of ACE and other aromatic compounds, taken alone (a, b, c,

351 d) or in mixture (e), under identical concentration, during the EF process on $500 \mathrm{~mL}$ (1-mM ACE)

352 and for different treatment times: (a) $10 \mathrm{~min}$, (b) $60 \mathrm{~min}$, (c) $80 \mathrm{~min}$, (d) $120 \mathrm{~min}$. (e) Mixture

353 solutions of standard ACE and aromatic compounds at different treatment times. 
At the end of electrolysis, the oxidation by $\bullet \mathrm{OH}$ generated during the EF process in

solution led to the production of ring-opened products such as aliphatic carboxylic acids. These acids such as formic acid or acetic acid are known to be low or non-toxic compounds (Liu et al., 2010). This suggestion was confirmed by their toxicity measurement presented in Fig. 7 in two ways: individual test on each single standard compound in MilliQ water at its maximum concentration measured during the EF process (Fig. 7a) and the combination (mixture) of all carboxylic by-products at their maximal concentrations measured during three periods of the electrolysis (Fig. 7b): 210-270 min (Mix 1); 270-330 min (Mix 2) and 330-480 min (Mix 3) (Table S3). Acetic and oxamic acids toxicity was measured for similar maximum concentration of about $0.5 \mathrm{mM}$, but oxamic acid seemed to promote higher toxicity than acetic acid with individual toxicity values of $25.7 \%$ and $7 \%$, respectively. The toxicity of maleic, oxalic and fumaric acids was around $15 \%$. In comparison with other intermediates, formic acid contributed negligibly to the toxicity of the solution. Interestingly, a cocktail effect was observed: synergistic (Mix 1) as well as antagonist effects (Mix 3) were observed during the comparative study on single and mixture of standard compounds. As observed in other studies with pesticides or antioxidants, the combinations of ACE carboxylic acid by-products did not induce an additive increase in individual toxicity (Liu et al., 2010). The toxicity of three mixtures decreased gradually as a function of treatment time, $18.7 \% ; 18.1 \%$ and $0 \%$, respectively, from 210 to $480 \mathrm{~min}$. These results confirmed that the EF process is an environmentally friendly technology, which can efficiently degrade toxic pollutants into non-toxic compounds.
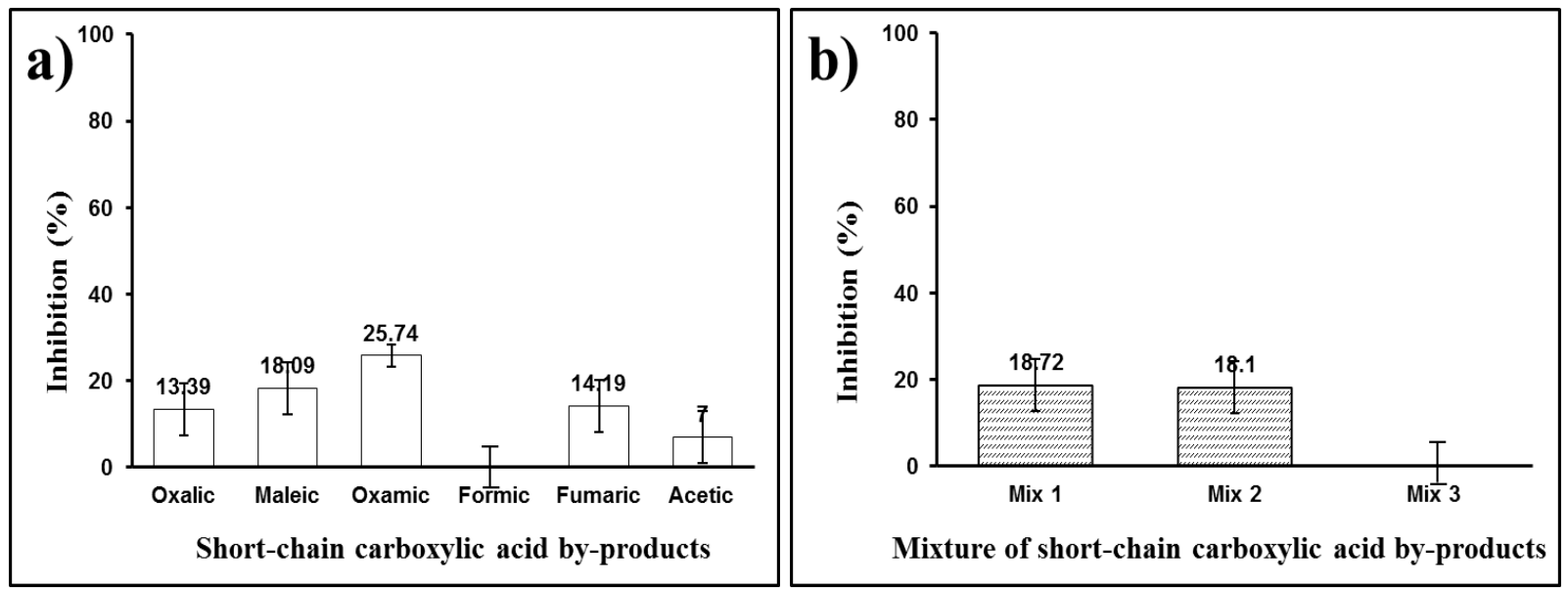
Fig. 7. Toxicity of (a) short-chain carboxylic acid by-products at their maximum concentrations (Table 3), and (b) Mixture of the short-chain carboxylic acid by-products corresponding to three periods: 210-270 min (Mix 1); 270-330 min (Mix 2) and 330-480 min (Mix 3) during EF treatment of $500 \mathrm{~mL}(1-\mathrm{mM} \mathrm{ACE})$ at $\mathrm{pH}=3 ;\left[\mathrm{Na}_{2} \mathrm{SO}_{4}\right]=50 \mathrm{mM}, \mathrm{I}=500 \mathrm{~mA},\left[\mathrm{Fe}^{2+}\right]=0.2 \mathrm{mM}$.

\section{Conclusions}

The evolution of TOC, intermediate compound concentrations and acute toxicity of ACE solution in aqueous medium during the EF mineralization process was monitored through HPLCUV/MS, IC, TOC analysis and Microtox ${ }^{\circledR}$ toxicity tests. During the first $60 \mathrm{~min}$ of treatment, the acute toxicity of the treated solution reached $100 \%$, which was identified on the basis of the formation of toxic aromatic products such as 1,4-benzoquinone, benzoic acid and benzaldehyde. A total detoxification of the solution was then accomplished after 120 min due to the decomposition of ring-compounds into short-chain carboxylic acids. The mineralization of ACE by hydroxyl radicals $(\cdot \mathrm{OH})$ formed through the EF process also produced inorganic ions such as ammonium or nitrate by bond breakage between nitrogen and carbon in the initial molecule. The mineralization of $200 \mathrm{~mL}$ of $0.1-\mathrm{mM}$ ACE was $86.9 \%$ using an applied current of $500 \mathrm{~mA}$ and a catalyst concentration of $0.2 \mathrm{mM}$. The relationship between the decomposition pathway and the evolution of the ACE solution toxicity as a function of EF treatment time was clarified by the toxicity measurement of both individual and mixture of standard compounds (ACE and sub-products). This comprehensive degradation pathway of ACE can be further applied to other persistent pharmaceuticals in an aquatic environment.

\section{Acknowledgement}

We gratefully acknowledge financial support from Vietnamese government (VIEDVietnam International Education Development - Project 911) and the ANR project 
ECOTS/CELECTRON for supplying materials and chemicals. We are also grateful to LABEX CHEMISYST and internal project PAT/ECOTOX for funding.

\section{References}

Abellán, M.N., Bayarri, B., Giménez, J., Costa, J., 2007. Photocatalytic degradation of sulfamethoxazole in aqueous suspension of TiO2. Applied Catalysis B: Environmental 74, 233-241.

Almeida, L.C., Garcia-Segura, S., Bocchi, N., Brillas, E., 2011. Solar photoelectro-Fenton degradation of paracetamol using a flow plant with a Pt/air-diffusion cell coupled with a compound parabolic collector: Process optimization by response surface methodology. Applied Catalysis B: Environmental 103, 21-30.

Andreozzi, R., Caprio, V., Marotta, R., Radovnikovic, A., 2003. Ozonation and H2O2/UV treatment of clofibric acid in water: a kinetic investigation. J Hazard Mater 103, 233-246.

Andreozzi, R., Caprio, V., Marotta, R., Vogna, D., 2003. Paracetamol oxidation from aqueous solutions by means of ozonation and $\mathrm{H}_{2} \mathrm{O}_{2}$ /UV system. Water Research 37, 993-1004.

Balcıoğlu, I. A., Ötker, M., 2003. Treatment of pharmaceutical wastewater containing antibiotics by $\mathrm{O}_{3}$ and $\mathrm{O}_{3} / \mathrm{H}_{2} \mathrm{O}_{2}$ processes. Chemosphere 50, 85-95.

Brillas, E., Sirés, I., Arias, C., Cabot, P.L., Centellas, F., Rodriguez, R.M., Garrido, J.A., 2005. Mineralization of paracetamol in aqueous medium by anodic oxidation with a boron-doped diamond electrode. Chemosphere 58, 399-406.

Brillas, E., Sirés, I., Oturan, M.A., 2009. Electro-Fenton Process and Related Electrochemical Technologies Based on Fenton's Reaction Chemistry. Chem. Rev. 109, 6570-6631.

Cabrera Reina, A., Santos-Juanes, L., García Sánchez, J.L., Casas López, J.L., Maldonado Rubio, M.I., Li Puma, G., Sánchez Pérez, J.A., 2015. Modelling the photo-Fenton oxidation of the pharmaceutical paracetamol in water including the effect of photon absorption (VRPA). Applied Catalysis B: Environmental 166-167, 295-301. 
Das, A., Chakrabarty, S., Choudhury, D., Chakrabarti, G., 2010. 1,4-Benzoquinone (PBQ) induced toxicity in lung epithelial cells is mediated by the disruption of the microtubule network and activation of caspase-3. Chem Res Toxicol 23, 1054-1066.

De Luna, M.D., Veciana, M.L., Su, C.C., Lu, M.C., 2012. Acetaminophen degradation by electro-Fenton and photoelectro-Fenton using a double cathode electrochemical cell. J Hazard Mater 217-218, 200-207.

Dirany, A., Sirés, I., Oturan, N., Ozcan, A., Oturan, M.A., 2012. Electrochemical treatment of the antibiotic sulfachloropyridazine: kinetics, reaction pathways, and toxicity evolution. Environ Sci Technol 46, 40744082.

Doll, T.E., Frimmel, F.H., 2003. Fate of pharmaceuticals—photodegradation by simulated solar UV-light. Chemosphere 52, 1757-1769.

Eggen, R.I., Hollender, J., Joss, A., Scharer, M., Stamm, C., 2014. Reducing the discharge of micropollutants in the aquatic environment: the benefits of upgrading wastewater treatment plants. Environ Sci Technol 48, 7683-7689.

Frontistis, Z., Daskalaki, V.M., Hapeshi, E., Drosou, C., Fatta-Kassinos, D., Xekoukoulotakis, N.P., Mantzavinos, D., 2012. Photocatalytic (UV-A/TiO2) degradation of $17 \alpha$-ethynylestradiol in environmental matrices: Experimental studies and artificial neural network modeling. Journal of Photochemistry and Photobiology A: Chemistry 240, 33-41.

García-Mateos, F.J., Ruiz-Rosas, R., Marqués, M.D., Cotoruelo, L.M., Rodríguez-Mirasol, J., Cordero, T., 2015. Removal of paracetamol on biomass-derived activated carbon: Modeling the fixed bed breakthrough curves using batch adsorption experiments. Chemical Engineering Journal 279, 18-30.

Gerrity, D., Gamage, S., Holady, J.C., Mawhinney, D.B., Quinones, O., Trenholm, R.A., Snyder, S.A., 2011. Pilot-scale evaluation of ozone and biological activated carbon for trace organic contaminant mitigation and disinfection. Water Research 45, 2155-2165.

Giannakis, S., Gamarra Vives, F.A., Grandjean, D., Magnet, A., De Alencastro, L.F., Pulgarin, C., 2015. Effect of advanced oxidation processes on the micropollutants and the effluent organic matter contained in 
municipal wastewater previously treated by three different secondary methods. Water Research 84 , 295-306.

Halling-Sørensen, B.,, Nors Nielsen, S., Lanzky, P.F., Ingerslev, F., Holten Lützhøft, H.C., Jørgensen, S.E., 1998. Occurrence, fate and effects of pharmaceutical substances in the environment- A review. Chemosphere 36, 357-393.

Hamdi El Najjar, N., Touffet, A., Deborde, M., Journel, R., Karpel Vel Leitner, N., 2014. Kinetics of paracetamol oxidation by ozone and hydroxyl radicals, formation of transformation products and toxicity. Separation and Purification Technology 136, 137-143.

Hammami, S., Bellakhal, N., Oturan, N., Oturan, M.A., Dachraoui, M., 2008. Degradation of Acid Orange 7 by electrochemically generated $(*) \mathrm{OH}$ radicals in acidic aqueous medium using a boron-doped diamond or platinum anode: a mechanistic study. Chemosphere 73, 678-684.

Huber, M.M., GÖbel, A., Joss, A., Hermann, N., LÖffler D., McArdell, C.S., Ried, A., Siegrist H., Ternes, T. A., Gunten, U.v., 2005. Oxidation of Pharmaceuticals during Ozonation of Municipal Wastewater Effluents: A Pilot Study. Environ Sci Technol 39, 4290-4299.

Huerta, B., Rodriguez-Mozaz, S., Nannou, C., Nakis, L., Ruhi, A., Acuna, V., Sabater, S., Barcelo, D., 2016. Determination of a broad spectrum of pharmaceuticals and endocrine disruptors in biofilm from a waste water treatment plant-impacted river. Sci Total Environ 540, 241-249.

Huerta-Fontela, M., Galceran, M.T., Ventura, F., 2011. Occurrence and removal of pharmaceuticals and hormones through drinking water treatment. Water Research 45, 1432-1442.

Irani, M., Rad, L.R., Pourahmad, H., Haririan, I., 2015. Optimization of the combined adsorption/photoFenton method for the simultaneous removal of phenol and paracetamol in a binary system. Microporous and Mesoporous Materials 206, 1-7.

Kabdaşli, I., Gürel, M., Tünay, O., 1999. Pollution prevention and waste treatment in chemical synthesis processes for pharmaceutical industry. Water Science and Technology 39, 265-271. 
Kolpin, D.W., Furlong, E.T., Meyer, M.T., Thurman, E.M., Zaugg, S.D., Barber, L.B., Buxton, H.T., 2002. Pharmaceuticals, Hormones, and Other Organic Wastewater Contaminants in U.S. Streams, 1999 2000: A National Reconnaissance. Environ. Sci. Technol. 36, 1202-1211.

Kulik, N., Trapido, M., Goi, A., Veressinina, Y., Munter, R., 2008. Combined chemical treatment of pharmaceutical effluents from medical ointment production. Chemosphere 70, 1525-1531.

Le, T.X.H., Bechelany, M., Lacour, S., Oturan, N., Oturan, M.A., Cretin, M., 2015a. High removal efficiency of dye pollutants by electron-Fenton process using a graphene based cathode. Carbon 94, 1003-1011.

Le, T. X.H., Bechelany M., Champavert J., Cretin, M., 2015b. A highly active based graphene cathode for the electro-fenton reaction. RSC Adv. 5, 42536.

Le, T.X.H., Charmette, C., Bechelany, M., Cretin, M., 2016. Facile Preparation of Porous Carbon Cathode to Eliminate Paracetamol in Aqueous Medium Using Electro-Fenton System. Electrochimica Acta 188, 378384.

Lee, P.Y., Chen, C.Y., 2009. Toxicity and quantitative structure-activity relationships of benzoic acids to Pseudokirchneriella subcapitata. J Hazard Mater 165, 156-161.

Lee, Y., Gerrity, D., Lee, M., Gamage, S., Pisarenko, A., Trenholm, R.A., Canonica, S., Snyder, S.A., von Gunten, U., 2016. Organic Contaminant Abatement in Reclaimed Water by UV/HO and a Combined Process Consisting of O/HO Followed by UV/HO: Prediction of Abatement Efficiency, Energy Consumption, and Byproduct Formation. Environ Sci Technol.

Leónidas A. Pérez-Estrada, Sixto Malato, Wolfgang Gernjak , Ana Agüera , E. Michael Thurman , Imma Ferrer , Fernández-Alba, A.R., 2005. Photo-Fenton Degradation of Diclofenac: Identification of Main Intermediates and Degradation Pathway. Environ Sci Technol 39, 8300-8306.

Liu, Z., Zhao, B., Guo, C., Sun, Y., Shi, Y., Yang, H., Li, Z., 2010. Carbon nanotube/raspberry hollow Pd nanosphere hybrids for methanol, ethanol, and formic acid electro-oxidation in alkaline media. J Colloid Interface Sci 351, 233-238. 
Margot, J., Kienle, C., Magnet, A., Weil, M., Rossi, L., de Alencastro, L.F., Abegglen, C., Thonney, D., Chevre, N., Scharer, M., Barry, D.A., 2013. Treatment of micropollutants in municipal wastewater: ozone or powdered activated carbon? Sci Total Environ 461-462, 480-498.

Molinari, R., Pirillo, F., Loddo, V., Palmisano, L., 2006. Heterogeneous photocatalytic degradation of pharmaceuticals in water by using polycrystalline $\mathrm{TiO} 2$ and a nanofiltration membrane reactor. Catalysis Today 118, 205-213.

Moreira, F.C., Boaventura, R.A.R., Brillas, E., Vilar, V.J.P., 2017. Electrochemical advanced oxidation processes: A review on their application to synthetic and real wastewaters. Applied Catalysis B: Environmental 202, 217-261.

Paulraj, M. G., Reegan, A. D., Ignacimuthu, S., 2011. Toxicity of Benzaldehyde and Propionic Acid against Immature and Adult Stages of Aedes aegypti (Linn.) and Culex quinquefasciatus (Say) (Diptera: Culicidae). Journal of Entomology 8, 539-547.

Rad, L.R., Irani, M., divsar, F., Pourahmad, H., Sayyafan, M.S., Haririan, I., 2015. Simultaneous degradation of phenol and paracetamol during photo-Fenton process: Design and optimization. Journal of the Taiwan Institute of Chemical Engineers 47, 190-196.

Reungoat, J., Escher, B.I., Macova, M., Argaud, F.X., Gernjak, W., Keller, J., 2012. Ozonation and biological activated carbon filtration of wastewater treatment plant effluents. Water Research 46, 863-872.

Reungoat, J., Macova, M., Escher, B.I., Carswell, S., Mueller, J.F., Keller, J., 2010. Removal of micropollutants and reduction of biological activity in a full scale reclamation plant using ozonation and activated carbon filtration. Water Research 44, 625-637.

Roberts, P.H., Thomas, K.V., 2006. The occurrence of selected pharmaceuticals in wastewater effluent and surface waters of the lower Tyne catchment. Sci Total Environ 356, 143-153.

Romero, A., Santos, A., Tojo, J., Rodriguez, A., 2008. Toxicity and biodegradability of imidazolium ionic liquids. J Hazard Mater 151, 268-273.

Rubio, V., Zhang, J., Valverde, M., Rojas, E., Shi, Z.Z., 2011. Essential role of Nrf2 in protection against hydroquinone- and benzoquinone-induced cytotoxicity. Toxicol In Vitro 25, 521-529. 
Ruiz, E.J., Hernández-Ramírez, A., Peralta-Hernández, J.M., Arias, C., Brillas, E., 2011. Application of solar photoelectro-Fenton technology to azo dyes mineralization: Effect of current density, Fe2+ and dye concentrations. Chemical Engineering Journal 171, 385-392.

Schwarzenbach, R.P., Escher, B.I., Fenner, K., Hofstetter, T.B., Johnson, C.A., von Gunten, U., Wehrli, B., 2006. The challenge of micropollutants in aquatic systems. Science 313, 1072-1077.

Sirés, I., Brillas, E., 2012. Remediation of water pollution caused by pharmaceutical residues based on electrochemical separation and degradation technologies: a review. Environ Int 40, 212-229.

Sirés, I., Brillas, E., Oturan, M.A., Rodrigo, M.A., Panizza, M., 2014. Electrochemical advanced oxidation processes: today and tomorrow. A review. Environ Sci Pollut Res Int 21, 8336-8367.

Sirés, I., Garrido, J.A., Rodríguez, R.M., Cabot, P.L., Centellas, F., Arias, C., Brillas, E., 2006. Electrochemical Degradation of Paracetamol from Water by Catalytic Action of $\mathrm{Fe}^{2+}, \mathrm{Cu}^{2+}$, and UVA Light on Electrogenerated Hydrogen Peroxide. Journal of The Electrochemical Society 153, DOI: 10.1149/1141.2130568.

Skoumal, M., Cabot, P.L., Centellas, F., Arias, C., Rodríguez, R.M., Garrido, J.A., Brillas, E., 2006. Mineralization of paracetamol by ozonation catalyzed with Fe2+, Cu2+ and UVA light. Applied Catalysis B: Environmental 66, 228-240.

Tekin, H., Bilkay, O., Ataberk, S.S., Balta, T.H., Ceribasi, I.H., Sanin, F.D., Dilek, F.B., Yetis, U., 2006. Use of Fenton oxidation to improve the biodegradability of a pharmaceutical wastewater. J Hazard Mater 136, 258-265.

Ternes, T.A., 1998. Occurrence of drugs in German sewage treatment plants and rivers. Water Research $32,3245-3260$.

Ternes, T.A., Meisenheimer, M., McDowell, D., Sacher, F., Brauch, H.-J. Haist-Gulde, B., Preuss, G., Wilme, U., Zulei-Seibert, N., 2002. Removal of pharmaceuticals during drinking water treatment. Environ Sci Technol 36, 3855-3863. 
Trovó, A.G., Melo, S.A.S., Nogueira, R.F.P., 2008. Photodegradation of the pharmaceuticals amoxicillin, bezafibrate and paracetamol by the photo-Fenton process-Application to sewage treatment plant effluent. Journal of Photochemistry and Photobiology A: Chemistry 198, 215-220.

Trovo, A.G., Pupo Nogueira, R.F., Aguera, A., Fernandez-Alba, A.R., Malato, S., 2012. Paracetamol degradation intermediates and toxicity during photo-Fenton treatment using different iron species. Water Research 46, 5374-5380.

Velegraki, T., Balayiannis, G., Diamadopoulos, E., Katsaounis, A., Mantzavinos, D., 2010. Electrochemical oxidation of benzoic acid in water over boron-doped diamond electrodes: Statistical analysis of key operating parameters, kinetic modeling, reaction by-products and ecotoxicity. Chemical Engineering Journal 160, 538-548.

Von Gunten, U., 2003. Ozonation of drinking water: Part I. Oxidation kinetics and product formation. Water Research 37, 1443-1467.

Yang, L., Yu, L.E., Ray, M.B., 2008b. Degradation of paracetamol in aqueous solutions by TiO2 photocatalysis. Water Res 42, 3480-3488.

Zhang, L., Yin, X., Li, S.F.Y., 2015. Bio-electrochemical degradation of paracetamol in a microbial fuel cellFenton system. Chemical Engineering Journal 276, 185-192.

Zhou, L., Hu, Z., Zhang, C., Bi, Z., Jin, T., Zhou, M., 2013. Electrogeneration of hydrogen peroxide for electro-Fenton system by oxygen reduction using chemically modified graphite felt cathode. Separation and Purification Technology 111, 131-136.

Zimmermann, S.G., Wittenwiler, M., Hollender, J., Krauss, M., Ort, C., Siegrist, H., von Gunten, U., 2011. Kinetic assessment and modeling of an ozonation step for full-scale municipal wastewater treatment: micropollutant oxidation, by-product formation and disinfection. Water Research 45, 605-617.

Zuccato, E., Calamari, D., Natangelo, M., Fanelli, R., 2000. Presence of therapeutic drugs in the environment. The Lancet 355, 1789-1790. 